\title{
New Uses for Traditional Crops: The Case of Barley Biofortification
}

\author{
Michalia Sakellariou and Photini V. Mylona * \\ Institute of Plant Breeding \& Genetic Resources, HAO-DEMETER, 57001 Thermi, Greece; \\ michsakellariou@yahoo.com \\ * Correspondence: phmylona@nagref.gr; Tel.: +30-2310-471-544
}

Received: 27 October 2020; Accepted: 9 December 2020; Published: 14 December 2020

check for updates

\begin{abstract}
Barley (Hordeum vulgare) is one of the oldest domesticated crops used for both human and animal feed. Over the years however, its role in human diet has been very limited and replaced by the broad use of wheat products. Nowadays, micronutrient deficiency, also known as hidden hunger, is one of the major challenges to human health worldwide. Biofortification of staple crops has been broadly accepted as the best strategy to overcome these limitations. Studies on the nutritional value of barley have proven its multiple benefits on human health and drove new attention towards the cultivation under the light of new food purposes. Biofortification of barley is approached through agronomic practices, conventional breeding, and/or the use of biotechnological tools and research results show that barley can be a promising crop for the emergence of novel food products with a significant impact on human nutrition.
\end{abstract}

Keywords: biofortification; grain crops; micronutrient deficiency; nutritional value; novel food products

\section{Introduction}

Micronutrient malnutrition, also known as hidden hunger, is one of the major challenges to human health in 21st century. Hidden hunger occurs when the food is deficient in vitamins and minerals and does not meet the nutrient requirements of people who consume it. Mineral deficiencies affect over two billion people globally, with Fe and Zn deficiency being the most common ones [1]. Several strategies have been implemented over the years to overcome micronutrient deficiency, the most important being through dietary diversification, supplementation, fortification, and biofortification of crop plants [2]. Dietary diversification aims to change food habits (e.g., increasing the consumption of animal-source food) at a household level, through nutritional education [3]. Supplementation strategy includes the consumption of concentrated nutrient sources (minerals and vitamins) in the form of pills, capsules, tablets, or liquids, while fortification refers to the enrichment of food products with additional micronutrients during processing [4]. Biofortification, defined as the process to increase genetically the bio-available mineral content of food crops, is considered a more sustainable and long-term approach to alleviate malnutrition compared to others, mainly due to the fact that mineral compound content is preserved after food processing or cooking [5]. Biofortification of staple crops, such as grains and cereals, has gained a lot of attention over the last decades and has caused a significant shift in the direction of breeding programs. This fact is also confirmed by the numerous scientific data that is available in this particular research field, as well as by the amount of publications, reviews, and books regarding biofortification of cereal crops [6] (pp. 93-109).

Barley (Hordeum vulgare) is considered one of the most important cereal crops, along with rice, corn, and wheat. The cultivation of barley has a large distribution worldwide and it ranks fourth both in production quantity and cultivated area among grain crops [7]. The largest part of barley production (up to $70 \%$ ) is being used as animal feed, about $21 \%$ is intended for malting, brewing, 
and distilling industries, leaving less than $6 \%$ of the production for human consumption [8]. However, studies showing the exceptional nutritional properties of the crop and their potential health benefits, suggest that barley could have a key role in human diet. The review focuses on the recent advances regarding barley biofortification strategies, under the light of the nutritional value of the crop and its potential for further use in food industry.

\section{Nutritional Value of Barley}

Over recent years, there has been a growing interest in expanding the use of barley as human food due to its high nutritional value. Whole grain barley has high levels of dietary fiber $(14.8 \mathrm{~g} / 100 \mathrm{~g}$ raw material) and good levels of other bioactive compounds and minerals, such as iron $(6 \mathrm{mg} / 100 \mathrm{~g}$ raw material), zinc ( $3.3 \mathrm{mg} / 100 \mathrm{~g}$ raw material), and calcium ( $50 \mathrm{mg} / 100 \mathrm{~g}$ raw material) [9]. According to the European Food Safety Authority report (EFSA), the daily dietary reference values of several nutrient elements for adults are 8-11 mg for zinc, 8-18 $\mathrm{mg}$ for iron, and $750 \mathrm{mg}$ for calcium, depending on gender [10]. Barley has a significantly higher protein content (10-20\%) compared to corn $(9.5 \%)$, rice bran (10-16\%), and wheat (14\%) [11]. Moreover, barley protein contains essential amino acids and is characterized by desirable functional properties (such as elasticity, water holding, and emulsifying capacity), which makes it an ideal component of food supplements [12,13]. Studies have shown barley to be an excellent source of dietary fiber and, in particular, $\beta$-glucan and antioxidant polyphenols [14,15]. Compared to other cereals, barley has the highest levels of $\beta$-glucan $(34.41 \pm 1.47 \mathrm{~g} / \mathrm{kg} \mathrm{db})$, followed by oat $(23.5 \pm 4.52 \mathrm{~g} / \mathrm{kg} \mathrm{db})$, rye $(15.6 \pm 0.36 \mathrm{~g} / \mathrm{kg} \mathrm{db})$, and wheat $(5.6 \pm 1.02 \mathrm{~g} / \mathrm{kg} \mathrm{db})$ [16]. Regular consumption of beta-glucan is linked to important health benefits, such as the control of cholesterol and blood glucose levels [17-19]. Barley is also considered an important dietary source of antioxidants, due to its vitamin $\mathrm{E}$ isomers (tocotrienols and tocopherols) content, which is reported to be higher compared to other cereals [20]. Antioxidants, such as vitamin E, play a major protective role against free radicals and thus, are important elements in human nutrition. Barley is the only grain crop to contain all eight vitamin E isomers [21]. Vitamin E content and antioxidant capacity in barley are reported to be genotype-dependent, proposing breeding strategies for potential functional food applications [22,23].

Due to barley's valuable bioactive compounds, barley flour is gaining more attention over the last years. Different types of barley flour, such as whole-grain, pearled, raw-grain flour, whole roasted-grains mature barley flour, and roasted-grain flour, are used for the production of bread, breakfast cereals, and baked products or as a mixture to improve wheat products [24-27]. Sprout flour was tested as a possible nutritious and functional ingredient, and it was found to retain $87 \%$ of the initial $\beta$-glucan content and higher levels of ascorbic acid, riboflavin, and phenolics compounds compared to nonsprouted grains [28]. The potential health benefits and nutritional value of barley and its by-products need to be further exploited in the production of novel functional foods, creating thus, new opportunities for both farmers and food manufacturers. Hence breeding programs should focus on developing new cultivars of prominent nutritional value including high levels of $\beta$-glucan, vitamin $E$ and antioxidants that are beneficial to human health, as well as on cultivars with improved sensory characteristics suited for different uses in food industry [29].

\section{Biofortification of Barley}

Biofortification of staple crops can be either achieved through agronomic intervention or genetic selection (conventional plant breeding methods and/or use of biotechnology techniques) aiming to increase the micronutrient content stored in the edible parts of the crop. In cereal crops biofortification emphasis is given to the improvement of mineral uptake from the soil, as well as to the partitioning and accumulation of minerals to the grains to enhance their bioavailability [30].

\subsection{Agronomic Biofortification}

Agronomic biofortification refers mainly to the application of foliar micronutrient fertilizers to cereal crops, but also includes other strategies to improve mineral content in grains, such as 
crop rotation [31-33], correcting soil alkalinity [34,35], and the introduction of beneficial soil microorganisms $[36,37]$. Foliar application of mineral fertilizers is widely used for the biofortification of cereals, as a quick and rather effective practice [38]. Results of experiments conducted under field conditions, using different application rates and sources of mineral fertilizers, showed significant increase of micronutrient content in barley crop from the first year of application, as well as in recurrent cropping cycles [39]. In some cases, this increase was combined with higher yield and grain protein content. Recent findings regarding the application of several fertilizers and their impact on grain mineral content are summarized in Table 1. Special mention is given on grain content, due to its role in human consumption. The initial nutrient content of raw grain in barley cultivars tested was on average $63.2 \mathrm{mg} / \mathrm{kg} \mathrm{Fe}, 65.7 \mathrm{mg} / \mathrm{kg} \mathrm{Zn}, 9.9 \mathrm{mg} / \mathrm{kg} \mathrm{Mn}, 4.6 \mathrm{mg} / \mathrm{kg} \mathrm{Cu}$, and $91.2 \mu \mathrm{g} / \mathrm{kg}$ Se. The achieved increase through ferti-fortification adds extra value to the existing nutrient content of the crop (Table 1). Although sufficient data is available on how to achieve better micronutrient content through fertilization in barley, still limited knowledge exists about the direct effect of these interventions on human health and further research is crucial.

Ferti-fortification (biofortification through fertilization) in barley (Hordeum vulgare) is mainly focused on the increase of bioavailable $\mathrm{Zn}$ and Fe content in grains, which are considered the major mineral deficiencies worldwide. Cereals accumulate excess $\mathrm{Zn}$ in root vacuoles from soil with the help of metal transporters of the ZIP (ZRT, IRT-related protein) family [40]. In order to increase the zinc content in the edible crop parts (grains), it is very important to enhance the root to shoot transfer system, as it is found that the translocation of zinc from leaves contributes more to the allocation of the element in the grains during filling stage, compared to recurrent uptake from soil [41]. Iron uptake from soil in cereal crops is conducted by the release of metal chelators (referred as Strategy II), which includes the biosynthesis of mugineic acid family phytosiderophores (MAs). Upon release of MAs to rhizosphere, iron solubilization and chelation is achieved followed by plant uptake [42]. Iron is further translocated within the plant by intercellular transport. Besides Strategy II, barley has a functional homolog of IRT1 (Iron-Regulated Transporter 1) that allows direct uptake of $\mathrm{Fe}^{2+}$ from the rhizosphere [43]. Cereals remobilize stored Fe from vegetative source organs into seeds (during senescence of leaves and grain filling), contributing to mineral accumulation in the grain [44]. The distribution of $\mathrm{Zn}$ and Fe within the barley grains is proven to be uneven, as the aleurone layer and embryo tissues have higher micronutrient concentration, compared to the endosperm [45]. Cereal grains used in the production of white flours (e.g., wheat and rice) undergo processing, where the outer layers of the grain (including the embryo) are removed and, thus, the final product for human consumption contains less Zn and Fe [46]. To overcome the nutrient loss during processing, wholegrain milling is preferred in the production of barley flour. It was shown that flour from biofortified barley grains had better physicochemical properties, compared to non-biofortified grains, under two different milling systems [47].

Studies have shown that micronutrient fertilization is most effective when combined with nitrogen-phosphorus-potassium (NPK) and organic fertilizers. Fertilization of spring barley, with NPK supplemented with sulphur has proven to beneficially affect the content of manganese, iron, zinc, and copper in the grain [39]. Zinc application in conjunction with urea was also tested in barley [48]. Results showed increase of $\mathrm{Zn}$ and protein content in the grain, suggesting a synergistic effect between $\mathrm{Zn}$ and $\mathrm{N}$. However, application rate and source of $\mathrm{Zn}$ and $\mathrm{N}$ have a different effect on mineral concentration $(\mathrm{Zn}, \mathrm{Fe}, \mathrm{Mn}$, and $\mathrm{Cu}$ ) in various parts of the plant (root, stem, leaves, and grain). Remarkably, an increase of $\mathrm{N}$ rate is positively correlated with grain protein content and yield (up to $13 \%$ of grain), but best results are obtained in combination to $\mathrm{Zn}$ fertilization [49]. Given the positive interaction between $\mathrm{Zn}$ and $\mathrm{N}$, probably due to the fact that $\mathrm{Zn}$ soil availability may have a role in metabolic and enzymatic activity, it is proposed that even biofortified varieties still need to be fertilized to reach high grain yield standards. While, $\mathrm{Zn}$ uptake and allocation in the cereal grain is strongly dependent on soil $\mathrm{Zn}$ availability and drought stress, as under both conditions zinc is remobilized from stems and leaves and accumulated in grains [50]. Studies have shown that in dry season conditions application of foliar fertilizers resulted in enrichment of barley grain mineral element content and 
antioxidant compounds such as carotenoids and glutathione. Conversely, under high precipitation levels, the concentration of essential elements in grain is decreased [51].

Taken together the above and the significant drought and heat stress tolerance of barley compared to the remaining cereal crops, the extension of its cultivation zone to marginal agricultural areas and poor soils, in semiarid and arid environments, typical of the Mediterranean basin is highly promising [52-57]. Cultivation of such lands with biofortified barley cultivars, with pronounced adaptation to adverse climatic conditions signalizes a solution to restrain land degradation due to climate change and loss of arable land, concurrently providing new opportunities for the production of crops and food products of high nutritional value in the prospect of economic development.

Another essential mineral element of fundamental importance to human health is selenium (Se). Selenium is known for its antioxidant, anticancer, antibacterial, and antiviral activity and its deficiency is linked to several diseases, including hypothyroidism and osteoarthropathy [58]. The final concentration of selenium in a crop is strongly affected by the quality of soil, which is subjected to factors such as rainfall, evaporation, and $\mathrm{pH}$ levels. Sodium selenite $\left(\mathrm{Na}_{2} \mathrm{SeO}_{3}\right)$ and sodium selenate $\left(\mathrm{Na}_{2} \mathrm{SeO}_{4}\right)$ are the main forms used in agronomic biofortification of crops. According to a meta-analysis review of the agronomic strategies followed in Se biofortification of crops, selenate is more effective in soil and foliar applications due to its weak adsorption on soil colloids compared to selenite, and therefore provides higher Se availability for plant uptake [59]. In cereal crops selenium is incorporated into selenomethionine (a protein reserved in grain endosperm) and, thus, it can be found in bioavailable concentrations in foods like white flours and polished grains for human diet [60-62]. In barley, the agronomic biofortification with selenium is attempted mainly through fertilization (soil or foliar application), or by addition during specific stages of malting process. Studies have shown that a significant increase in selenium grain content can be achieved by the application of either $\mathrm{Na}_{2} \mathrm{SeO}_{4}$ or $\mathrm{Na}_{2} \mathrm{SeO}_{3}$ in soil (Table 1), but further investigation is needed to determine how much of the Se gain in the grain is maintained after the manufacturing process [63]. It was shown that only $7.3 \%$ of the Se accumulated in barley grains was retained in beer after malting and brewing processes. Despite the significant loss in Se content in the final product, beer made from biofortified barley had 6-fold higher Se concentration compared to beer made from nonfertilized barley [64]. The production of Se-biofortified beer could be a new challenge for the brewing industry.

Table 1. Cumulative data on increase of micronutrient concentration in barley grain with the application of mineral fertilizers under field conditions.

\begin{tabular}{|c|c|c|}
\hline Treatment- Application & Element Concentration Increase (\%) & Source \\
\hline $\begin{array}{l}\text { ZnCHE fertilizers } \\
\mathrm{N} \text { (urea) }\end{array}$ & $\begin{array}{l}\mathrm{Zn} \text { content up to } 30 \% \\
\mathrm{Zn} \text { content up to } 8 \%\end{array}$ & [49] \\
\hline Sulphur fertilization & $\begin{array}{l}\text { Mn content increase } 19.2 \% \\
\text { Fe content increase } 19.5 \% \\
\text { Zn content increase } 16.5 \%\end{array}$ & [39] \\
\hline $\mathrm{ZnSO}_{4}$ and urea & Zn content increase $42 \%$ & [48] \\
\hline $\begin{array}{l}\text { Foliar fertilizers and hormonal } \\
\text { growth stimulators }\end{array}$ & $\begin{array}{l}\text { No significant increase in Fe content } \\
\text { Zn content up to } 40 \% \\
\text { No significant increase in Mn content }\end{array}$ & [51] \\
\hline Foliar Se fertilizer $\left(\mathrm{Na}_{2} \mathrm{SeO}_{4}\right)$ & Se content increase $6.5 \%$ & [65] \\
\hline $\mathrm{Na}_{2} \mathrm{SeO}_{3}$ in soil & Se content increase up to $50 \%$ & [66] \\
\hline $\mathrm{Na}_{2} \mathrm{SeO}_{4}$ and $\mathrm{Na}_{2} \mathrm{SeO}_{3}$ in soil & Se content increase 33-fold compared to control & [63] \\
\hline $\mathrm{Na}_{2} \mathrm{SeO}_{3}$ in soil & Se content increase up to $45 \%$ & {$[67]$} \\
\hline Foliar Se fertilizer $\left(\mathrm{Na}_{2} \mathrm{SeO}_{4}\right)$ & Se content increase 25 -fold compared to control & [68] \\
\hline
\end{tabular}


The use of soil or foliar mineral fertilizers although very effective at short time periods, is also a significant recurrent expenditure for farmers. In addition, their application must be precise in terms of the adequate dose and time-dependent to cover several developmental stages of the crop. It becomes clear that weather conditions can easily affect or even prevent a successful implementation in the field, resulting in reduced effectiveness of fertilizers. An alternative method for the agronomic biofortification of barley could be the use of intercropping systems and the introduction of beneficial soil microorganisms. Intercropping between dicots and gramineous species can offer an effective and sustainable pathway to iron and zinc biofortification [69].

Among the beneficial soil microorganisms the plant growth promoting microbes play a significant role in crop production, as they may stimulate plant growth and development directly by nitrogen fixation, phosphorus, potassium, and zinc solubilization [70]. Particularly, the plant growth promoting rhizobacteria (PGPR) embrace bacteria that colonize plant roots and possess several mechanisms to sequester macro- and micronutrients from soil, increasing, thus, their bioavailability to the crop plants [37]. Therefore, biofortification with microorganisms can be a supplemental method in the ferti-fortification of cereal crops to increase the nutrient content of the grain and soil fertility. Several cyanobacteria strains and actinomycetes have proven to improve significantly the nutritional quality of grains ( $\mathrm{Zn}, \mathrm{Fe}, \mathrm{Cu}, \mathrm{Mn}$, and protein content) when combined with fertilization [36,71]. In barley, metabolites of Acetobacter aceti were found to alter the crop metabolic processes and enhance vitamin content in seeds [72]. Significant increase in the uptake of $\mathrm{N}, \mathrm{Fe}, \mathrm{Mn}$, and $\mathrm{Zn}$ in barley was achieved through plant-microbe interactions with nitrogen-fixing Bacillus licheniformis RC02, Rhodobacter capsulatus RC04, Paenibacillus polymyxa RC05, Pseudomonas putida RC06, and Bacillus OSU-142. Studies suggest that PGPRs stimulate growth in barley through the production of hormones [73].

Besides bacteria arbuscular mycorrhizal fungi (AMF) were also shown to have a significant role in nutrient uptake. The role of AMF in cereal crops nutrient uptake pathway was examined in combination with $\mathrm{Zn}$ fertilization applications. Studies on AMF inoculation effect in barley have shown that responsiveness to nutrient concentration, physiological traits, and yield parameters, is strongly dependent on barley cultivar, AMF strain (Rhizophagus irregularis is vastly used, but the effect of Glomus mosseau and Fumiliformis mosseau has also been tested in barley cultivars), soil condition, climatic conditions, and dose of applied fertilization [74-76]. Hence inoculation of barley cultivars with AMF Rhizophagus irregularis had a positive effect on ZIP transporter genes in the roots (significant upregulation of HvZIP13 gene), resulting in increased zinc concentrations in both grain and straw, but lack yield improvement [77]. Comparative studies of the role of AMF colonization in wheat and barley have shown different responses in nutrient uptake and yield components of the crops. The mycorrhizal pathway of $\mathrm{Zn}$ uptake had a higher contribution in wheat $(24.3 \%)$ compared to barley $(12.7 \%)$, but the best contribution for each crop was achieved under the highest $\mathrm{Zn}$ addition for wheat and under the lowest for barley [78]. In general, AMF inoculation has a greater positive effect on grain nutrient content in barley rather than in wheat, but mineral elements are located in the aleurone layer, which is removed during processing and therefore poses a limiting factor in the agronomic biofortification of the crop [79]. It is noteworthy that the majority of the studies concerning the role of AMF in nutrient uptake of barley are conducted in controlled environments (greenhouse experiments on pots). Thus, further research is required to evaluate these interactions in field conditions.

\subsection{Genetic Biofortification}

\subsubsection{Breeding}

Plant genetic resources of cereal crops and their wild relatives deposited in gene banks are a valuable source of alleles for improvement of the nutritional value of grains of modern varieties via conventional breeding. Germplasm screening of wild populations and local landraces is essential to estimate the available variation of macronutrient and micronutrient concentrations in barley. Studies have shown that a great variation of nutrient concentration exists in barley grains, which is 
still not fully exploited [80-82]. Analyzing the genetic control of nutrient concentration in mature barley grains indicated that numerous genomic regions determine the final nutritional value of grains and wild alleles were frequently associated with higher nutrient concentrations [83]. Introgression of such alleles could enable the development of well-adapted biofortified varieties of barley. However, the time investment needed to develop a new grain variety (estimated over 10 years) entirely by means of conventional breeding, poses a significant limitation to biofortification breeding programs.

On the other hand, quantitative trait loci (QTL) mapping can facilitate the study of complex traits, such as mineral accumulation in grains. Identified QTLs for Fe and Zn accumulation in cereals have proven to be colocalized, but also related to other important minerals (P and $\mathrm{Ca}$ ) and agronomical traits, such as grain protein content and grain weight. Colocalization of desired QTLs implies common mechanisms of transport, paving thus the way towards the development of DNA markers associated to these traits, which could be used in marker assisted selection (MAS) for the development of biofortified varieties [43].

QTL for grain protein content (GPC) was first mapped in wild emmer wheat (Triticum dicoccoides) and it was found to have a positive effect on Fe and $\mathrm{Zn}$ concentration in the grain [84]. Subsequently GPC locus was found in barley and HvNAM-1 gene was identified as homologous to wheat TtNAM-B1 gene (GPC-B1 locus). Studies on recombinant inbred line (RIL) populations of barley, segregating the molecular markers HVM74 and ABG458 (genetically linked to GPC locus), have shown that GPC locus is associated with leaf senescence and $\mathrm{N}$ remobilization compounds, which may improve translocation of $\mathrm{Zn}$ and Fe to barley grains $[85,86]$. Genetic linkage mapping of a double-haploid barley population ('Clipper' $x$ 'Sahara') has led to the identification of six QTLs associated with Zn remobilization from stem and leaves into grains [87,88]. Meanwhile 46 QTLs were identified in introgression lines (ILs) of barley (Hordeum vulgare ssp. spontaneum $\times$ 'Scarlett'), regarding the accumulation of both essential nutrients ( $\mathrm{Zn}$ and $\mathrm{Fe}$ ) and toxic elements (i.e., $\mathrm{Cd}$ ) in barley grains [89]. Genome wide association studies (GWAS) have been used for the identification and mapping of QTLs linked to micronutrient accumulation in barley grains. Mamo et al. (2014) estimated the genetic variability in zinc and iron concentration in more than 3000 Ethiopian/Eritrean barley landraces using 7842 single nucleotide polymorphism (SNP) markers [90]. Forty-five QTLs were associated with concentration of 11 elements (2 QTL for Ba, 2 for $\mathrm{Ca}, 4$ for $\mathrm{Cu}, 11$ for Fe, 2 for $\mathrm{K}, 3$ for $\mathrm{Mg}, 6$ for $\mathrm{Mn}, 4$ for $\mathrm{Na}, 3$ for S, 5 for Si, and 3 for $\mathrm{Zn}$ ) were mapped in barley chromosomes, through GWA study of 336 spring barley genotypes using 6519 SNP markers [91]. Nested association mapping (NAM) in wild barley combined with GWAS identified 75 QTL hotspots related to 15 grain elements. Most of them could be related to major genes such as NO APICAL MERISTEM-1 (NAM-1) and PHOTOPERIOD 1 (Ppd-H1). Additionally, the GWAS approach revealed exotic alleles that were able to increase grain element concentrations. More importantly, a QTL linked to GIBBERELLIN 20 OXIDASE 2 (HvGA20ox2) increased several grain elements without yield loss [92].

\subsubsection{Genetic Engineering}

In recent decades genetic engineering has been considered a dynamic approach to cereal crops biofortification. The main objective is the incorporation of selected genes encoding traits though genome editing and the overexpression of those that regulate efficiently the biosynthesis and/or the accumulation of minerals and other health beneficial compounds, for the improvement of new grain varieties. Several limitations of conventional plant breeding, such as time and effectiveness, can be overcome with the use of novel molecular techniques and biotechnology tools, through the screening of large barley populations and the selection of outperforming genotypes in a single generation. However, the genetic biofortification of cereal crops is often complicated by the fact that several traits concerning mineral uptake and accumulation are highly dependent on many physiological factors and agronomic parameters [93].

On the other hand, genome editing with the use of site-specific nucleases, has greatly facilitated the isolation and incorporation of desirable genes into the genome of elite cultivars rapidly and 
efficiently, offering new opportunities in crop improvement. Till recently, the two main tools for plant genome editing were the zinc finger nucleases (ZFNs) and the transcription activator-like effector nucleases (TALENs). Both systems have a DNA-binding domain, which can be engineered to recognize a specific DNA sequence. However, the design and construction of large modular proteins is both laborious and expensive [94]. These limitations were overcome with the emergence of CRISPR/Cas9 (clustered regularly interspaced short palindromic repeats/CRISPR associated protein 9) system, which is an RNA-guided genome editing tool that consists of a Cas9 nuclease and a single guide RNA (sgRNA). Compared with ZFNs and TALENs, the CRISPR/Cas9 system is much easier to be constructed and specific gene targeting can be achieved easily by changing the synthetic sgRNA sequence [95]. The simplicity and high precision of the CRISPR/Cas9 system has revolutionized genome editing and ever since its emergence it has been widely utilized in the improvement of a vast range of crop plants [96-99]. The CRISPR/Cas9 system has been successfully employed for biofortification purposes in barley. Targeted knockout mutations of HvHPT and HvHGGT genes have been created to study their implication in vitamin E biosynthesis pathways in barley [100]. The role of barley phytase gene HvPAPhy_a was investigated in knockout mutant lines, as phytases are known for providing bioavailable phosphate for grain germination, accounting for $70-80 \%$ of the total $\mathrm{P}$ in cereal grains [101]. New D-hordein alleles were created in barley using the CRISPR/Cas9 system, providing a new germplasm source for the study of D-hordein protein function in barley, which will enable the development of new cultivars with better malt quality [102].

The zinc content in barley has been enhanced via overexpression of zinc ( $\mathrm{Zn}$ )-regulated, iron-regulated transporter-like protein (ZIP) genes. Overexpression of HvZIP7 in barley plants increased Zn uptake when moderately high concentrations of Zn were supplied [103]. Transgenic barley plants overexpressing Arabidopsis zinc transporter gene AtZIP1 had total zinc and iron content two times higher than control. In addition, contents of magnesium and calcium increased about 0.5 times [104]. Root engineering could be a promising strategy to improve nutrient uptake in cereal crops. Transgenic barley plants expressing a cytokinin-degrading CYTOKININ OXIDASE/DEHYDROGENASE $(C K X)$ gene in their roots form a larger root system and accumulate a higher concentration of $\mathrm{Zn}$ in their grains (up to $44 \%$ under greenhouse conditions and up to $30 \%$ when grown in the field) compared to the untransformed control, suggesting that this is a stable trait $[105,106]$.

\section{Conclusions and Future Prospects}

Biofortification of staple crops, such as cereals, is a successful approach for dealing with micronutrient deficiencies worldwide. Over the last decades, great achievements have been made in this direction, especially for crops like wheat and rice. However, climate change adaptation entails agronomic strategies shifting towards resilient crops which can tolerate stress, exhibit better adaptation to adverse climatic conditions, and can be cultivated in marginal lands without significant yield loss. Barley is a crop that gathers all the features mentioned above, and in addition its grains are characterized by high nutritional value. Biofortification of barley could signal the production of novel products and functional foods, which will enhance mineral element consumption in human diet. Barley biofortification strategies have been thoroughly described and cover the main approaches: agronomic, breeding, and use of biotechnology and genetic engineering. Agronomic biofortification of barley is proven to have important results, even in poor soils and rainfed systems, where the crop is well-adapted. Conventional breeding is helpful for the evaluation of wild germplasm populations, but the introgression of desired characteristic through crossings is very labor and time demanding, and therefore no significant progress has been achieved in barley biofortification. On the other hand, the use of novel biotechnology techniques (-omics and genome editing) facilitates robust germplasm evaluation and crop biofortification by developing varieties with increased grain microelement content through the identification of QTLs and genes associated with nutrient uptake and accumulation in barley grains. 
Despite the method followed to achieve biofortification in barley crop, great attention must be given in the processing of the edible parts (grains), in order to mitigate or even avoid loss of nutrient elements. Microminerals are usually accumulated in the aleurone layer, which is removed during milling and processing. Therefore, there is a great need for new uses of old crops, like barley, in order to enrich human diet. Whole-grain processing could be one option which will allow the development of novel products, such as flours, baked products, pasta, breakfast cereals, etc. using entirely barley grains or as a mixture with other grain crops. The introduction of such products in human diet is considered very important as it will bring significant health benefits to the consumer.

Funding: This research received no external funding.

Acknowledgments: The authors wish to thank the support of EU-LIFE program under the grant agreement LIFE16 CCA/GR/000050.

Conflicts of Interest: The authors declare no conflict of interest.

\section{References}

1. WHO. Micronutrient Deficiency: Iron Deficiency Anaemia; WHO/NHD/01.3; World Health Organization (WHO): Geneva, Switzerland, 2007. Available online: http://www.who.int./nutrition/topics/ida/ (accessed on 27 October 2020).

2. Rawat, N.; Neelam, K.; Tiwari, V.K.; Dhaliwal, H.S. Biofortification of cereals to overcome hidden hunger. Plant Breed. 2013, 132, 437-445. [CrossRef]

3. Nair, M.K.; Augustine, L.F.; Konapur, A. Food-Based Interventions to Modify Diet Quality and Diversity to Address Multiple Micronutrient Deficiency. Front. Public Health 2016, 3, 277. [CrossRef] [PubMed]

4. Mannar, M.G.V.; Wesley, A.S. Food Fortification. In International Encyclopedia of Public Health; Elsevier: Amsterdam, The Netherlands, 2016; ISBN 9780128037089.

5. Singh, U.; Praharaj, C.S.; Singh, S.S.; Singh, N.P. Biofortification of Food Crops; Springer: Berlin, Germany, 2016; ISBN 9788132227168.

6. Gupta, O.P.; Pandey, V.; Narwal, S.; Sharma, P.; Ram, S.; Singh, G.P. Wheat and Barley Grain Biofortification; Woodhead Publishing: Sawston, UK; Cambridge, UK, 2020; ISBN 9780128184448.

7. FAO. World Food and Agriculture - Statistical Pocketbook 2018; FAO: Rome, Italy, 2018. [CrossRef]

8. Tricase, C.; Amicarelli, V.; Lamonaca, E.; Leonardo Rana, R. Economic Analysis of the Barley Market and Related Uses. In Grasses as Food and Feed; IntechOpen: London, UK, 2018.

9. Langridge, P. Economic and Academic Importance of Barley. In The Barley Genome; Springer: Berlin, Germany, 2018.

10. Dietary Reference Values for nutrients Summary report. EFSA Support. Publ. 2017, 14. [CrossRef]

11. Gong, L. Barley. In Bioactive Factors and Processing Technology for Cereal Foods; Wang, J., San, B., Tsao, R., Eds.; Springer: Berlin, Germany, 2019. [CrossRef]

12. Wang, C.; Tian, Z.; Chen, L.; Temelli, F.; Liu, H.; Wang, Y. Functionality of Barley Proteins Extracted and Fractionated by Alkaline and Alcohol Methods. Cereal Chem. 2010, 87, 597-606. [CrossRef]

13. Huang, H. Content analysis of vitamins, dietary fibers and amino acids in a wide collection of barley (Hordeum vulgare L.) from Tibet, China. Bioinformation 2020, 16, 314-322. [CrossRef] [PubMed]

14. Sullivan, P.; Arendt, E.; Gallagher, E. The increasing use of barley and barley by-products in the production of healthier baked goods. Trends Food Sci. Technol. 2013, 29, 124-134. [CrossRef]

15. Šimić, G.; Horvat, D.; Dvojković, K.; Abičić, I.; Vuletić, M.V.; Tucak, M.; Lalić, A. Evaluation of total phenolic content and antioxidant activity of malting and hulless barley grain and malt extracts. Czech J. Food Sci. 2017, 35, 73-78. [CrossRef]

16. Menkovska, M.; Damjanovski, D.; Levkov, V.; Gjorgovska, N.; Knezevic, D.; Nikolova, N.; Stanoev, V. Content of B-glucan in cereals grown by organic and conventional farming. Banat. J. Biotechnol. 2017, 8, $39-47$. [CrossRef]

17. Tong, L.-T.; Zhong, K.; Liu, L.; Zhou, X.; Qiu, J.; Zhou, S. Effects of dietary hull-less barley $\beta$-glucan on the cholesterol metabolism of hypercholesterolemic hamsters. Food Chem. 2015, 169, 344-349. [CrossRef]

18. Wang, Y.; Harding, S.V.; Thandapilly, S.J.; Tosh, S.M.; Jones, P.J.H.; Ames, N.P. Barley $\beta$-glucan reduces blood cholesterol levels via interrupting bile acid metabolism. Br. J. Nutr. 2017, 118, 822-829. [CrossRef] 
19. Velikonja, A.; Lipoglavšek, L.; Zorec, M.; Orel, R.; Avguštin, G. Alterations in gut microbiota composition and metabolic parameters after dietary intervention with barley beta glucans in patients with high risk for metabolic syndrome development. Anaerobe 2019, 55, 67-77. [CrossRef] [PubMed]

20. Panfili, G.; Fratianni, A.; Irano, M. Normal Phase High-Performance Liquid Chromatography Method for the Determination of Tocopherols and Tocotrienols in Cereals. J. Agric. Food Chem. 2003, 51, 3940-3944. [CrossRef] [PubMed]

21. Granda, L.; Rosero, A.; Benešová, K.; Pluháčková, H.; Neuwirthová, J.; Cerkal, R. Content of Selected Vitamins and Antioxidants in Colored and Nonpigmented Varieties of Quinoa, Barley, and Wheat Grains. J. Food Sci. 2018, 83, 2439-2447. [CrossRef] [PubMed]

22. Do, T.D.T.; Cozzolino, D.; Muhlhausler, B.; Box, A.; Able, A.J. Antioxidant capacity and vitamin E in barley: Effect of genotype and storage. Food Chem. 2015, 187, 65-74. [CrossRef]

23. Martínez, M.; Motilva, M.J.; López de las Hazas, M.C.; Romero, M.P.; Vaculova, K.; Ludwig, I.A. Phytochemical composition and $\beta$-glucan content of barley genotypes from two different geographic origins for human health food production. Food Chem. 2018, 245, 61-70. [CrossRef]

24. Mariotti, M.; Garofalo, C.; Aquilanti, L.; Osimani, A.; Fongaro, L.; Tavoletti, S.; Hager, A.-S.; Clementi, F. Barley flour exploitation in sourdough bread-making: A technological, nutritional and sensory evaluation. LWT Food Sci. Technol. 2014, 59, 973-980. [CrossRef]

25. Collar, C.; Angioloni, A. Nutritional and functional performance of high $\beta$-glucan barley flours in breadmaking: Mixed breads versus wheat breads. Eur. Food Res. Technol. 2014, 238, 459-469. [CrossRef]

26. Blandino, M.; Locatelli, M.; Gazzola, A.; Coïsson, J.D.; Giacosa, S.; Travaglia, F.; Bordiga, M.; Reyneri, A.; Rolle, L.; Arlorio, M. Hull-less barley pearling fractions: Nutritional properties and their effect on the functional and technological quality in bread-making. J. Cereal Sci. 2015, 65, 48-56. [CrossRef]

27. Narwal, S.; Kumar, D.; Sheoran, S.; Verma, R.P.S.; Gupta, R.K. Hulless barley as a promising source to improve the nutritional quality of wheat products. J. Food Sci. Technol. 2017, 54, 2638-2644. [CrossRef]

28. Rico, D.; Peñas, E.; del Carmen García, M.; Martínez-Villaluenga, C.; Rai, D.K.; Birsan, R.I.; Frias, J.; Martín-Diana, A.B. Sprouted Barley Flour as a Nutritious and Functional Ingredient. Foods 2020, 9, 296. [CrossRef]

29. Farag, M.A.; Xiao, J.; Abdallah, H.M. Nutritional value of barley cereal and better opportunities for its processing as a value-added food: A comprehensive review. Crit. Rev. Food Sci. Nutr. 2020, 1-13. [CrossRef] [PubMed]

30. Welch, R.M. Breeding Strategies for Biofortified Staple Plant Foods to Reduce Micronutrient Malnutrition Globally. J. Nutr. 2002, 132, 495S-499S. [CrossRef] [PubMed]

31. Venkatesh, M.S.; Hazra, K.K.; Ghosh, P.K.; Khuswah, B.L.; Ganeshamurthy, A.N.; Ali, M.; Singh, J.; Mathur, R.S. Long-term effect of crop rotation and nutrient management on soil-plant nutrient cycling and nutrient budgeting in Indo-Gangetic plains of India. Arch. Agron. Soil Sci. 2017, 63, 2007-2022. [CrossRef]

32. Łukowiak, R.; Grzebisz, W.; Sassenrath, G.F. New insights into phosphorus management in agriculture-A crop rotation approach. Sci. Total Environ. 2016, 542, 1062-1077. [CrossRef] [PubMed]

33. Bakhshandeh, S.; Corneo, P.E.; Mariotte, P.; Kertesz, M.A.; Dijkstra, F.A. Effect of crop rotation on mycorrhizal colonization and wheat yield under different fertilizer treatments. Agric. Ecosyst. Environ. 2017, 247, $130-136$. [CrossRef]

34. Khoshgoftarmanesh, A.H.; Norouzi, M.; Afyuni, M.; Schulin, R. Zinc biofortification of wheat through preceding crop residue incorporation into the soil. Eur. J. Agron. 2017, 89, 131-139. [CrossRef]

35. Brown, L.K.; Blanz, M.; Wishart, J.; Dieterich, B.; Schmidt, S.B.; Russell, J.; Martin, P.; George, T.S. Is Bere barley specifically adapted to fertilisation with seaweed as a nutrient source? Nutr. Cycl. Agroecosystems 2020, 118, 149-163. [CrossRef]

36. Rana, A.; Joshi, M.; Prasanna, R.; Shivay, Y.S.; Nain, L. Biofortification of wheat through inoculation of plant growth promoting rhizobacteria and cyanobacteria. Eur. J. Soil Biol. 2012, 50, 118-126. [CrossRef]

37. Prasanna, R.; Nain, L.; Rana, A.; Shivay, Y.S. Biofortification with microorganisms: Present status and future challenges. In Biofortification of Food Crops; Springer: New Delhi, India, 2016; ISBN 9788132227168.

38. Dapkekar, A.; Deshpande, P.; Oak, M.D.; Paknikar, K.M.; Rajwade, J.M. Getting more micronutrients from wheat and barley through agronomic biofortification. In Wheat and Barley Grain Biofortification; Woodhead Publishing: Sawston/Cambridge, UK, 2020. 
39. Barczak, B.; Jastrzębska, M.; Kostrzewska, M.K. Biofortification of Spring Barley Grain with Microelements through Sulfur Fertilization. J. Chem. 2019, 2019, 1-7. [CrossRef]

40. Palmgren, M.G.; Clemens, S.; Williams, L.E.; Krämer, U.; Borg, S.; Schjørring, J.K.; Sanders, D. Zinc biofortification of cereals: Problems and solutions. Trends Plant Sci. 2008, 13, 464-473. [CrossRef]

41. Jatav, H.S.; Singh, S.K.; Gautam, M.K.; Khan, M.; Kumar, S.; Rajput, V.D.; Khan, M.A.; Jat, L.K.; Parihar, M.; Khatik, C.L.; et al. Zinc Solubilization and Mobilization: A Promising Approach for Cereals Biofortification. In Advances in Plant Microbiome and Sustainable Agriculture; Springer: Singapore, 2020.

42. Vasconcelos, M.W.; Gruissem, W.; Bhullar, N.K. Iron biofortification in the 21st century: Setting realistic targets, overcoming obstacles, and new strategies for healthy nutrition. Curr. Opin. Biotechnol. 2017, 44, 8-15. [CrossRef] [PubMed]

43. Garcia-Oliveira, A.L.; Chander, S.; Ortiz, R.; Menkir, A.; Gedil, M. Genetic Basis and Breeding Perspectives of Grain Iron and Zinc Enrichment in Cereals. Front. Plant Sci. 2018, 9, 937. [CrossRef] [PubMed]

44. Connorton, J.M.; Balk, J. Iron Biofortification of Staple Crops: Lessons and Challenges in Plant Genetics. Plant Cell Physiol. 2019, 60, 1447-1456. [CrossRef] [PubMed]

45. Detterbeck, A.; Pongrac, P.; Persson, D.P.; Vogel-Mikuš, K.; Kelemen, M.; Vavpetič, P.; Pelicon, P.; Arčon, I.; Husted, S.; Kofod Schjoerring, J.; et al. Temporal and Spatial Patterns of Zinc and Iron Accumulation during Barley (Hordeum vulgare L.) Grain Development. J. Agric. Food Chem. 2020, 68, 12229-12240. [CrossRef]

46. Narwal, S.; Gupta, O.P.; Pandey, V.; Kumar, D.; Ram, S. Effect of storage and processing conditions on nutrient composition of wheat and barley. In Wheat and Barley Grain Biofortification; Woodhead Publishing: Sawston/Cambridge, UK, 2020.

47. Acar, O.; Izydorczyk, M.S.; Kletke, J.; Yazici, M.A.; Ozdemir, B.; Cakmak, I.; Koksel, H. Effects of roller and hammer milling on the yield and physicochemical properties of fibre-rich fractions from biofortified and non-biofortified hull-less barley. J. Cereal Sci. 2020, 92, 102907. [CrossRef]

48. Gonzalez, D.; Almendros, P.; Obrador, A.; Alvarez, J.M. Zinc application in conjunction with urea as a fertilization strategy for improving both nitrogen use efficiency and the zinc biofortification of barley. J. Sci. Food Agric. 2019, 99, 4445-4451. [CrossRef]

49. Almendros, P.; Obrador, A.; Álvarez, J.M.; Gonzalez, D. Zn-DTPA-HEDTA-EDTA Application: A Strategy to Improve the Yield and Plant Quality of a Barley Crop While Reducing the N Application Rate. J. soil Sci. Plant Nutr. 2019, 19, 920-934. [CrossRef]

50. Cakmak, I.; Kutman, U.B. Agronomic biofortification of cereals with zinc: A review. Eur. J. Soil Sci. 2018, 69, 172-180. [CrossRef]

51. Dragičević, V.D.; Nikolić, B.R.; Radosavljević, M.M.; Durić, N.A.; Dodig, D.B.; Stoiljković, M.M.; Kravić, N.B. Barley grain enrichement with essential elements by agronomic biofortification. Acta Period. Technol. 2016, 47, 1-9. [CrossRef]

52. Kharub, A.S.; Singh, J.; Lal, C.; Kumar, V. Abiotic stress tolerance in barley. In Abiotic Stress Management for Resilient Agriculture; Springer: Singapore, 2017; ISBN 9789811057441.

53. Schmidt, S.B.; George, T.S.; Brown, L.K.; Booth, A.; Wishart, J.; Hedley, P.E.; Martin, P.; Russell, J.; Husted, S. Ancient barley landraces adapted to marginal soils demonstrate exceptional tolerance to manganese limitation. Ann. Bot. 2019, 123, 831-843. [CrossRef]

54. Kahiluoto, H.; Kaseva, J.; Balek, J.; Olesen, J.E.; Ruiz-Ramos, M.; Gobin, A.; Kersebaum, K.C.; Takáč, J.; Ruget, F.; Ferrise, R.; et al. Decline in climate resilience of European wheat. Proc. Natl. Acad. Sci. USA 2019, 116, 123-128. [CrossRef] [PubMed]

55. Pasam, R.K.; Sharma, R.; Walther, A.; Özkan, H.; Graner, A.; Kilian, B. Genetic Diversity and Population Structure in a Legacy Collection of Spring Barley Landraces Adapted to a Wide Range of Climates. PLoS ONE 2014, 9, e116164. [CrossRef] [PubMed]

56. Cai, K.; Chen, X.; Han, Z.; Wu, X.; Zhang, S.; Li, Q.; Nazir, M.M.; Zhang, G.; Zeng, F. Screening of Worldwide Barley Collection for Drought Tolerance: The Assessment of Various Physiological Measures as the Selection Criteria. Front. Plant Sci. 2020, 11, 1159. [CrossRef] [PubMed]

57. Dawson, I.K.; Russell, J.; Powell, W.; Steffenson, B.; Thomas, W.T.B.; Waugh, R. Barley: A translational model for adaptation to climate change. New Phytol. 2015, 206, 913-931. [CrossRef]

58. Lyons, G. Biofortification of Cereals With Foliar Selenium and Iodine Could Reduce Hypothyroidism. Front. Plant Sci. 2018, 9, 730. [CrossRef] 
59. Ros, G.H.; Van Rotterdam, A.M.D.; Bussink, D.W.; Bindraban, P.S. Selenium fertilization strategies for bio-fortification of food: An agro-ecosystem approach. Plant Soil 2016, 404, 99-112. [CrossRef]

60. Broadley, M.R.; Alcock, J.; Alford, J.; Cartwright, P.; Foot, I.; Fairweather-Tait, S.J.; Hart, D.J.; Hurst, R.; Knott, P.; McGrath, S.P.; et al. Selenium biofortification of high-yielding winter wheat (Triticum aestivum L.) by liquid or granular Se fertilisation. Plant Soil 2010, 332, 5-18. [CrossRef]

61. Sharma, S.; Kaur, N.; Kaur, S.; Nayyar, H. Selenium as a nutrient in biostimulation and biofortification of cereals. Indian J. Plant Physiol. 2017, 22, 1-15. [CrossRef]

62. Lidon, F.C.; Oliveira, K.; Ribeiro, M.M.; Pelica, J.; Pataco, I.; Ramalho, J.C.; Leitão, A.E.; Almeida, A.S.; Campos, P.S.; Ribeiro-Barros, A.I.; et al. Selenium biofortification of rice grains and implications on macronutrients quality. J. Cereal Sci. 2018, 81, 22-29. [CrossRef]

63. Rodrigo, S.; Santamaría, O.; López-Bellido, F.J.; Poblaciones, M.J. Agronomic selenium biofortification of two-rowed barley under Mediterranean conditions. Plant Soil Environ. 2013, 59, 115-120. [CrossRef]

64. Rodrigo, S.; Santamaria, O.; Chen, Y.; McGrath, S.P.; Poblaciones, M.J. Selenium Speciation in Malt, Wort, and Beer Made from Selenium-Biofortified Two-Rowed Barley Grain. J. Agric. Food Chem. 2014, 62, 5948-5953. [CrossRef]

65. Sajedi, N.A.; Madani, H. Comparison of physiological and biochemical responses of wheat and barley to Selenium by spraying application under rain fed conditions. Iran. J. Plant Physiol. 2018, 8, 2381-2389. [CrossRef]

66. Yilmaz, S.; Ilbaş, A.I.; Akbulut, M.; Çetin, A. Grain amino acid composition of barley (Hordeum vulgare L.) cultivars subjected to selenium doses. Turk. J. Biochem. 2018, 43, 268-276. [CrossRef]

67. Ilbas, A.I.; Yilmaz, S.; Akbulut, M.; Bogdevich, O. Uptake and distribution of selenium, nitrogen and sulfur in three barley cultivars subjected to selenium applications. J. Plant Nutr. 2012, 35, 442-452. [CrossRef]

68. Gibson, C.; Park, Y.H.; Myoung, K.H.; Suh, M.K.; McArthur, T.; Lyons, G. The biofortification of barley with selenium. In Proceedings of the Institute of Brewery \& Distillating (Asia-Pacific Section) Carventron, Hobart, Tasmania, Australia, 19-24 March 2006.

69. Zuo, Y.; Zhang, F. Iron and zinc biofortification strategies in dicot plants by intercropping with gramineous species: A review. In Agronomy for Sustainable Development; Springer: Berlin, Germany, 2009; ISBN 9789048126651.

70. Khan, A.; Singh, J.; Upadhayay, V.K.; Singh, A.V.; Shah, S. Microbial biofortification: A green technology through plant growth promoting microorganisms. In Sustainable Green Technologies for Environmental Management; Springer: Singapore, 2019; ISBN 9789811327728.

71. Hozzein, W.N.; Abuelsoud, W.; Wadaan, M.A.M.; Shuikan, A.M.; Selim, S.; Al Jaouni, S.; AbdelGawad, H. Exploring the potential of actinomycetes in improving soil fertility and grain quality of economically important cereals. Sci. Total Environ. 2019, 651, 2787-2798. [CrossRef]

72. Yousaf, A.; Qadir, A.; Anjum, T.; Ahmad, A. Identification of Microbial Metabolites Elevating Vitamin Contents in Barley Seeds. J. Agric. Food Chem. 2015, 63, 7304-7310. [CrossRef] [PubMed]

73. Singh, D.; Prasanna, R.; Sharma, V.; Rajawat, M.V.S.; Nishanth, S.; Saxena, A.K. Prospecting plant-microbe interactions for enhancing nutrient availability and grain biofortification. In Wheat and Barley Grain Biofortification; Woodhead Publishing: Sawston/Cambridge, UK, 2020.

74. Moshfeghi, N.; Heidari, M.; Reza Asghari, H.; Firoz Abadi, M.B.; Abbott, L.K.; Chen, Y. Effect of zinc foliar application and mycorrhizal inoculation on morpho-physiological traits and yield parameters of two barley cultivars. Ital. J. Agron. 2019, 14, 67-77. [CrossRef]

75. Moshfeghi, N.; Heidari, M.; Asghari, H.R.; Abadi, M.B.F.; Abbott, L.K.; Chen, Y. Foliar application of nano-Zn and mycorrhizal inoculation enhanced $\mathrm{Zn}$ in grain and yield of two barley (Hordeum vulgare) cultivars under field conditions. Aust. J. Crop Sci. 2020, 14, 475-484. [CrossRef]

76. Al Mutairi, A.A.; Cavagnaro, T.R.; Khor, S.F.; Neumann, K.; Burton, R.A.; Watts-Williams, S.J. The effect of zinc fertilisation and arbuscular mycorrhizal fungi on grain quality and yield of contrasting barley cultivars. Funct. Plant Biol. 2020, 47, 122-133. [CrossRef]

77. Watts-Williams, S.J.; Cavagnaro, T.R. Arbuscular mycorrhizal fungi increase grain zinc concentration and modify the expression of root ZIP transporter genes in a modern barley (Hordeum vulgare) cultivar. Plant Sci. 2018, 274, 163-170. [CrossRef] 
78. Coccina, A.; Cavagnaro, T.R.; Pellegrino, E.; Ercoli, L.; McLaughlin, M.J.; Watts-Williams, S.J. The mycorrhizal pathway of zinc uptake contributes to zinc accumulation in barley and wheat grain. BMC Plant Biol. 2019, 19, 1-14. [CrossRef] [PubMed]

79. Watts-Williams, S.J.; Gilbert, S.E. Arbuscular mycorrhizal fungi affect the concentration and distribution of nutrients in the grain differently in barley compared with wheat. Plants People Planet 2020. [CrossRef]

80. Detterbeck, A.; Pongrac, P.; Rensch, S.; Reuscher, S.; Pečovnik, M.; Vavpetič, P.; Pelicon, P.; Holzheu, S.; Krämer, U.; Clemens, S. Spatially resolved analysis of variation in barley (Hordeum vulgare) grain micronutrient accumulation. New Phytol. 2016, 211, 1241-1254. [CrossRef] [PubMed]

81. Gyawali, S.; Otte, M.L.; Jacob, D.L.; Abderrazek, J.; Singh Verma, R.P. Multiple element concentration in the grain of spring barley (Hordeum vulgare L.) collection. J. Plant Nutr. 2019, 42, 1036-1046. [CrossRef]

82. Yan, J.; Wang, F.; Qin, H.; Chen, G.; Eviatar, N.; Fahima, T.; Cheng, J. Natural Variation in Grain Selenium Concentration of Wild Barley, Hordeum spontaneum, Populations from Israel. Biol. Trace Elem. Res. 2011, 142, 773-786. [CrossRef] [PubMed]

83. Wiegmann, M.; Thomas, W.T.B.; Bull, H.J.; Flavell, A.J.; Zeyner, A.; Peiter, E.; Pillen, K.; Maurer, A. “Wild barley serves as a source for biofortification of barley grains". Plant Sci. 2019, 283, 83-94. [CrossRef] [PubMed]

84. Joppa, L.R.; Du, C.; Hart, G.E.; Hareland, G.A. Mapping Gene(s) for Grain Protein in Tetraploid Wheat (Triticum turgidum L.) Using a Population of Recombinant Inbred Chromosome Lines. Crop Sci. 1997, 37, 1586-1589. [CrossRef]

85. Distelfeld, A.; Korol, A.; Dubcovsky, J.; Uauy, C.; Blake, T.; Fahima, T. Colinearity between the barley grain protein content (GPC) QTL on chromosome arm 6HS and the wheat Gpc-B1 region. Mol. Breed. 2008, 22, 25-38. [CrossRef]

86. Jukanti, A.K.; Fischer, A.M. A high-grain protein content locus on barley (Hordeum vulgare) chromosome 6 is associated with increased flag leaf proteolysis and nitrogen remobilization. Physiol. Plant. 2008, 132, 426-439. [CrossRef]

87. Hussain, S.; Rengel, Z.; Mohammadi, S.A.; Ebadi-Segherloo, A.; Maqsood, M.A. Mapping QTL associated with remobilization of zinc from vegetative tissues into grains of barley (Hordeum vulgare). Plant Soil 2016, 399, 193-208. [CrossRef]

88. Sadeghzadeh, B.; Rengel, Z.; Li, C. Quantitative Trait Loci (QTL) of Seed Zn Accumulation in Barley Population Clipper X Sahara. J. Plant Nutr. 2015, 38, 1672-1684. [CrossRef]

89. Reuscher, S.; Kolter, A.; Hoffmann, A.; Pillen, K.; Krämer, U. Quantitative Trait Loci and Inter-Organ Partitioning for Essential Metal and Toxic Analogue Accumulation in Barley. PLoS ONE 2016, 11, e0153392. [CrossRef] [PubMed]

90. Mamo, B.E.; Barber, B.L.; Steffenson, B.J. Genome-wide association mapping of zinc and iron concentration in barley landraces from Ethiopia and Eritrea. J. Cereal Sci. 2014, 60, 497-506. [CrossRef]

91. Gyawali, S.; Otte, M.L.; Chao, S.; Jilal, A.; Jacob, D.L.; Amezrou, R.; Verma, R.P.S. Genome wide association studies (GWAS) of element contents in grain with a special focus on zinc and iron in a world collection of barley (Hordeum vulgare L.). J. Cereal Sci. 2017, 77, 266-274. [CrossRef]

92. Herzig, P.; Backhaus, A.; Seiffert, U.; Von Wirén, N.; Pillen, K.; Maurer, A. Genetic dissection of grain elements predicted by hyperspectral imaging associated with yield-related traits in a wild barley NAM population. Plant Sci. 2019, 285, 151-164. [CrossRef] [PubMed]

93. Narwal, S.; Kumar, D.; Kharub, A.S.; Verma, R.P.S. Barley biofortification: Present status and future prospects. In Wheat and Barley Grain Biofortification; Woodhead Publishing: Sawston/Cambridge, UK, 2020.

94. Dwivedi, S.L.; Scheben, A.; Edwards, D.; Spillane, C.; Ortiz, R. Assessing and Exploiting Functional Diversity in Germplasm Pools to Enhance Abiotic Stress Adaptation and Yield in Cereals and Food Legumes. Front. Plant Sci. 2017, 8, 1461. [CrossRef]

95. Bortesi, L.; Fischer, R. The CRISPR/Cas9 system for plant genome editing and beyond. Biotechnol. Adv. 2015, 33, 41-52. [CrossRef]

96. Arora, L.; Narula, A. Gene Editing and Crop Improvement Using CRISPR-Cas9 System. Front. Plant Sci. 2017, 8, 1932. [CrossRef]

97. Jaganathan, D.; Ramasamy, K.; Sellamuthu, G.; Jayabalan, S.; Venkataraman, G. CRISPR for Crop Improvement: An Update Review. Front. Plant Sci. 2018, 9, 985. [CrossRef]

98. Chen, K.; Wang, Y.; Zhang, R.; Zhang, H.; Gao, C. CRISPR/Cas Genome Editing and Precision Plant Breeding in Agriculture. Annu. Rev. Plant Biol. 2019, 70, 667-697. [CrossRef] 
99. Bao, A.; Burritt, D.J.; Chen, H.; Zhou, X.; Cao, D.; Tran, L.S.P. The CRISPR/Cas9 system and its applications in crop genome editing. Crit. Rev. Biotechnol. 2019, 39, 321-336. [CrossRef] [PubMed]

100. Zeng, Z.; Han, N.; Liu, C.; Buerte, B.; Zhou, C.; Chen, J.; Wang, M.; Zhang, Y.; Tang, Y.; Zhu, M.; et al. Functional dissection of HGGT and HPT in barley vitamin E biosynthesis via CRISPR/Cas9-enabled genome editing. Ann. Bot. 2020, 126, 929-942. [CrossRef] [PubMed]

101. Holme, I.B.; Wendt, T.; Gil-Humanes, J.; Deleuran, L.C.; Starker, C.G.; Voytas, D.F.; Brinch-Pedersen, H. Evaluation of the mature grain phytase candidate HvPAPhy_a gene in barley (Hordeum vulgare L.) using CRISPR/Cas9 and TALENs. Plant Mol. Biol. 2017, 95, 111-121. [CrossRef] [PubMed]

102. Li, Y.; Liu, D.; Zong, Y.; Jiang, L.; Xi, X.; Cao, D.; Shen, Y.; Zhang, H.; Liu, B. New D hordein alleles were created in barley using CRISPR/Cas9 genome editing. Cereal Res. Commun. 2020, 48, 131-138. [CrossRef]

103. Tiong, J.; McDonald, G.K.; Genc, Y.; Pedas, P.; Hayes, J.E.; Toubia, J.; Langridge, P.; Huang, C.Y. HvZIP7 mediates zinc accumulation in barley (Hordeum vulgare) at moderately high zinc supply. New Phytol. 2014, 201, 131-143. [CrossRef]

104. Mrízová, K.; Holasková, E.; Öz, M.T.; Jiskrová, E.; Frébort, I.; Galuszka, P. Transgenic barley: A prospective tool for biotechnology and agriculture. Biotechnol. Adv. 2014, 32, 137-157. [CrossRef] [PubMed]

105. Ramireddy, E.; Galuszka, P.; Schmülling, T. Zn-fortified cereal grains in field-grown barley by enhanced root cytokinin breakdown. Plant Signal. Behav. 2018, 13, e1530023. [CrossRef]

106. Ramireddy, E.; Hosseini, S.A.; Eggert, K.; Gillandt, S.; Gnad, H.; Von Wirén, N.; Schmülling, T. Root Engineering in Barley: Increasing Cytokinin Degradation Produces a Larger Root System, Mineral Enrichment in the Shoot and Improved Drought Tolerance. Plant Physiol. 2018, 177, 1078-1095. [CrossRef]

Publisher's Note: MDPI stays neutral with regard to jurisdictional claims in published maps and institutional affiliations. 